\title{
The effects of El Niño and La Niña on snow and avalanche patterns in British Columbia, Canada, and central Chile
}

\author{
D.M. MCCLUNG \\ Department of Geography, University of British Columbia, Vancouver, British Columbia, Canada \\ E-mail: mcclung@geog.ubc.ca
}

\begin{abstract}
El Niño and La Niña affect global climate and atmospheric circulation to determine winter temperature and precipitation patterns. Both winter temperatures and the associated precipitation patterns have effects on mountain snow deposition and snow avalanche occurrences. Approximately 25000 slab avalanches from 30 winters were analyzed in relation to snowfall patterns contrasted for El Niño and La Niña winters for two avalanche areas with different snow climates in British Columbia (BC), Canada. La Niña winters were shown to produce more snow, more avalanches and a higher percentage of dry avalanches than wet avalanches. The data and analysis show that the avalanche patterns depend on the altitude and snow climate. Analysis of snowfall and accident data from the Andes of Chile suggests behavior opposite to BC. El Niño winters in central Chile produced the most snow and, by inference, the most avalanches. This paper is the first to show the links of El Niño and La Niña to snow avalanche activity.
\end{abstract}

\section{INTRODUCTION}

In Canada, snow avalanches account for more fatalities than any other natural hazard. In British Columbia (BC), Canada, avalanches have major effects on the transportation routes: every railway is threatened, and 62 areas along British Columbia highways, with 1350 avalanche paths, need forecasting, protection and avalanche control. Snow avalanches have important effects on the biggest industries in British Columbia including forestry, mining and winter tourism (McClung and Schaerer, 2006). In BC, La Niña winters are known to produce more snow and generally lower temperatures than El Niño winters (Moore and McKendry, 1996; Stahl and others, 2006) In this paper, the amount of snow received and the avalanching characteristics are contrasted for El Niño and La Niña winters for two avalanche areas in BC (Bear Pass and Kootenay Pass (Fig. 1)) with 30 winters of avalanche occurrence records (24560). Total amounts of snow received and the number of slab avalanches recorded, stratified by avalanche size and water content (dry or wet), are considered. Figure 2 shows a dry slab avalanche of size 3 in motion (Table 7 in Appendix A describes the Canadian avalanche size system (McClung and Schaerer, 2006)). The definition of El Niño and La Niña winters is similar to that of Redmond (2005) based on analysis of sea surface temperatures (SSTs) off the west coast of South America.

The results provide the first comprehensive study to contrast the effects of El Niño and La Niña winters on snow avalanche activity. There are numerous papers dealing with avalanches and time/climate effects (e.g. Laternser and Schneebeli, 2002; Keylock, 2003; García-Sellés and others, 2010; Castebrunet and others, 2012). However, none of these contain snow data, nor mention of El Niño/La Niña, and all deal with European mountain areas. Fitzharris (1981) made an extensive pioneering study of the frequency and climatology of major avalanches at Rogers Pass, BC. However, the effects of La Niña/El Niño and snow amounts were not considered. The results here show more snow, more avalanches and a higher percentage of dry avalanches for La Niña winters. The effect on avalanche size is best illustrated from Bear Pass data which show correlation of maximum annual snow depth and total number of large dry avalanches $(\geq$ size 3$)$ is negligible. Analysis of snow data from central Chile provides results opposite to BC: El Niño winters produce the most snow and, by inference, the most avalanches.

Stahl and others (2006) provide the physical reasons for the contrasting winter snow and temperature patterns between El Niño and La Niña in BC, backed by analysis from climate stations. One factor is that El Niño winters favour a split in the jet stream in the mid-Pacific to produce storm tracks that avoid southern BC. The reader is referred to Stahl and others (2006) for more information. In Chile, the SSTs off the coast influence the storm tracks, with warmer SSTs during El Niño (low pressure off the coast; Bryant, 2005) favouring more snow storms striking the Andes than during La Niña winters or normal conditions with cold SSTs (high pressure off the coast). The Chilean data are important since they show the results from BC cannot be extrapolated directly to other areas.

\section{DEFINITION OF EL NIÑO AND LA NIÑA WINTERS FROM SEA SURFACE TEMPERATURES}

The definition of El Niño and La Niña winters used here is similar to that by Redmond (2005). The preceding July through December (3 month moving average SSTs provided by the US National Weather Service (USNWS, 2011)) were used to determine a yearly index. The Oceanic Niño Index (ONI; $\left.{ }^{\circ} \mathrm{C}\right)$ (USNWS, 2011) was an average of six monthly values per year to determine a mean SST index based on SST anomalies in the Niño 3.4 region $\left(5^{\circ} \mathrm{N}-5^{\circ} \mathrm{S}\right.$, $\left.120-170^{\circ} \mathrm{W}\right)$. The values are relative to the mean for the 1971-2000 base period (USNWS, 2011). This gave 61 individual values (1950/51 through 2010/11). Figure 3 shows the calculated values for the ONI by year. Below, the units on the $\mathrm{ONI}$ are omitted for brevity and the $\mathrm{ONI}$ values are denoted by $x$. 


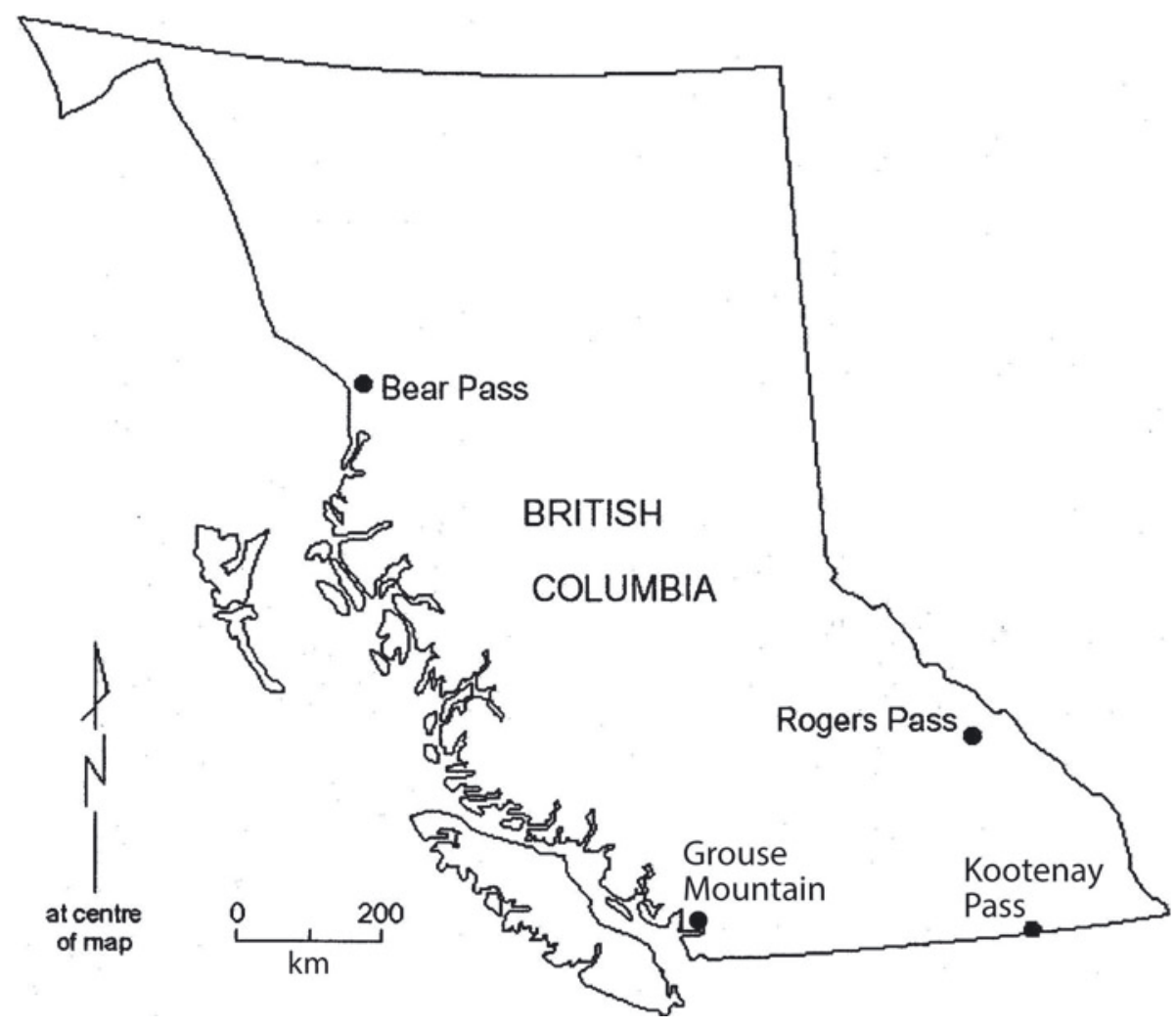

Fig. 1. Locations of the four snow stations analyzed.

The mean value of the $\mathrm{ONI}$ (95\% confidence limits) is $+0.025(-0.18$ to 0.23$)$ and the median is -0.1 . The range is -1.6 to +2.2 and with skewness 0.18 . The skewness is not statistically significant since the ratio of skewness to standard error of skewness is 0.6 and less than the value of 2 needed for significance. A time-series trend analysis is performed on the ONI data in Figure 3. The Mann-Kendall test gave $p=0.13$ which is not statistically significant.

Two definitions of El Niño and La Niña winters are used in this study. An El Niño winter was specified when $x>0.23$, and a La Niña winter was specified when $x<-0.18$. The winter was defined neutral for values between these $95 \%$ confidence limits on the mean of $x$. The second definition was for strong winters. A strong El Niño winter was defined

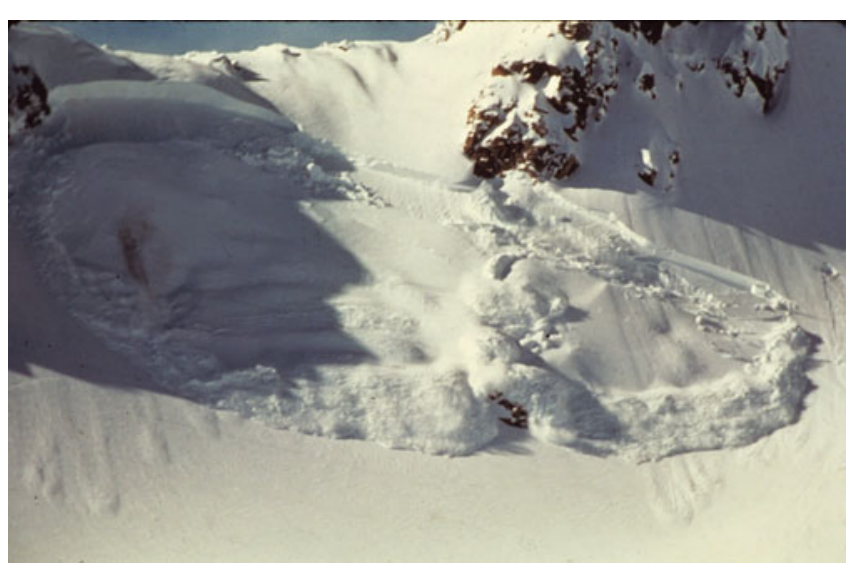

Fig. 2. A dry slab avalanche (size 3) in motion at Whistler Bowl, BC. Photograph by T. Salway. when $x>0.6$ (upper 25\%), and a strong La Niña winter when $x<-0.6$ (lower 25\%), with neutral winters for $|x| \leq 0.6$.

The 61 yearly index values $(x)$ were fit to a probability density function (PDF). The cumulative distribution function (CDF) allowed estimates of return period for different index

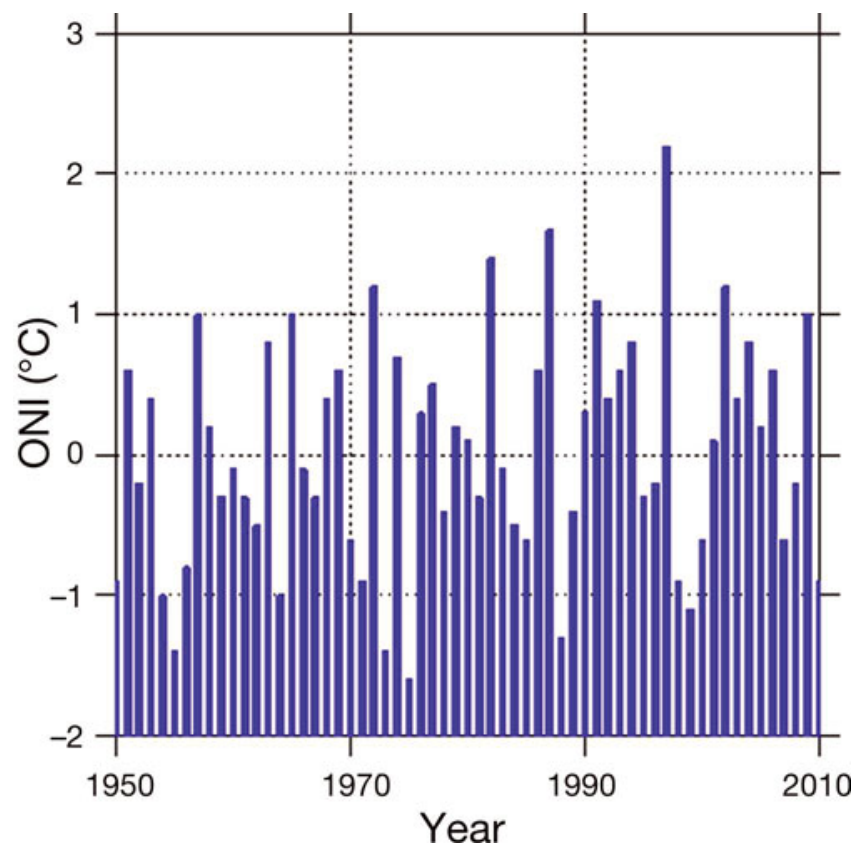

Fig. 3. ONI vs year. The index was calculated from the average of SST values using six monthly (each a 3 month moving average) values from July through December. 
values. For the analysis, 65 PDFs were tried and a fit was obtained for 39 of them. The best fit was based on five goodness-of-fit criteria: the Kolmogorov-Smirnov (K-S) statistic $(0.056 ; 0.135)$, the Anderson-Darling (A-D) statistic $(0.20,1.37)$, the Chi-Squared (C-S) statistic $(3.23,7.29)$, the probability plot (P-P) and the quantile (Q-Q) plot. In the parentheses, the first number is the statistic, and the second is the critical value based on the level-of-significance parameter $\alpha=0.2$ (Walpole and Myers, 1978), which is more stringent than the usual value $(\alpha=0.05)$.

The best fit was provided by a generalized extreme value (GEV) PDF with $k, \sigma, \mu$ (shape, scale, location parameters) as $-0.24,0.81,-0.28$. The CDF for the GEV PDF is given by $F(x)=\exp \left(-(1+k z)^{-1 / k}\right)$ where $z=(x-\mu) / \sigma$. Figure 4 shows the $\mathrm{ONI}$ on a quantile probability plot with a leastsquares line $\left(R^{2}=0.99\right)$. The quantile is defined by $\mu+(\sigma / k)\left[\left(-\ln \{F(x)\}^{-1}\right)-1\right]$ using rank order statistics with the CDF represented by Hazen plotting positions with non-exceedance probability $P=(i-0.5) / 61$, with $i$ as the rank (1-61) from the lowest to highest value of $x$.

The return periods, $T(x)$, for strong $\mathrm{El}$ Niño and La Niña winters were defined as $T(0.6)=1 /[1-F(0.6)]$; $T(-0.6)=1 / F(-0.6)$ respectively. The $25 \%(x=-0.6)$ or $75 \%(x=0.6)$ quartile values gave return periods equal to 4 years for strong La Niña or El Niño years. Calculations of sample statistics gave 12 strong La Niña years $(x<-0.6)$ and 13 strong El Niño years $(x>0.6)$. The discrepancy between these values and the expected return period values $(\sim 15$ values each) arose since some of the years had values equal to -0.6 and 0.6. Throughout the analysis below, the sample values were used: 12 strong La Niña years and 13 strong El Niño years for the 61 year dataset. The extreme El Niño year of 1997 ( $x=2.2$; Fig. 4) was estimated to have a return period of $\sim 250$ years $\{T(2.2)=1 /[1-F(2.2)]\}$. However, the return period estimate is an unreasonable extrapolation given only 61 years of data.

\section{METHODS AND DATA CHARACTERISTICS}

The variables used in this study are given in Table 8 in Appendix A. To help place Bear Pass and Kootenay Pass within climate zones, maximum annual snow depth data were analyzed. Since the main emphasis here is on avalanche activity, the annual maximum snow data are contained in Appendix B which includes the locations (Fig. 1) and descriptive statistics for both snow stations.

At Bear Pass, personnel of the BC Ministry of Environment (Province of British Columbia, 2011) measured the annual maximum snow depths from monthly measurements throughout the snow season. The annual maximum snow depths for Kootenay Pass were determined from daily depth measurements by the BC Ministry of Transportation and Infrastructure.

The total snow amounts for El Indio, Chile (3869 ma.s.I.), and Minera Los Pelambres (3130 ma.s.I.) in central Chile (Section 6) were obtained by mine personnel by summing the total depth of snow from individual storms over the course of the snow season. The El Indio site is $500 \mathrm{~km}$ north of Santiago, and Minera Los Pelambres is $200 \mathrm{~km}$ north of Santiago.

The avalanche occurrence records at Bear and Kootenay Pass were from daily observations by resident avalanche technicians of the BC Ministry of Transportation and Infrastructure. Among the variables reported were the avalanche size; whether the avalanches were slab (those used in

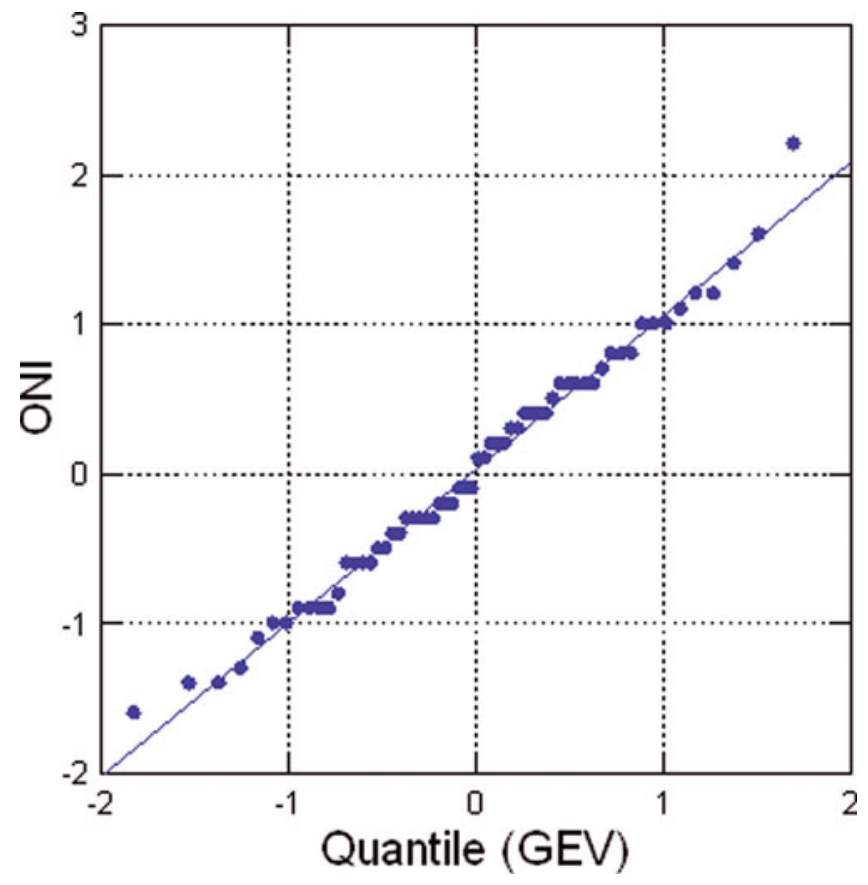

Fig. 4. Probability plot for the ONI vs quantiles for the GEV PDF. The outlier at the right (2.2) is the record year of 1997.

this study) or loose; and the water content of the avalanche deposit (dry, moist or wet) (Fierz and others, 2009).

All Canadian data adhered to the observation and recording standards published by the Canadian Avalanche Association (2007), the first edition of which was published in 1981 as Technical Memorandum No. 132 from the National Research Council of Canada.

\subsection{Snow climates for Bear Pass and Kootenay Pass}

Alpine snow climates (Armstrong and Armstrong, 1987; Hägeli and McClung, 2003; Haegeli, 2004; McClung and Schaerer, 2006) are classified as maritime, continental or transitional between the two. A maritime snow climate usually has high amounts of snow, winter temperatures that can fluctuate to produce rain at any time during the winter and a relatively warm snowpack. A continental snow climate generally has low amounts of snow, mostly low temperatures throughout the winter and a dry snowpack. A transitional snow climate lies between these two extremes. The character of a snowpack and the avalanches that occur also depend on altitude, with the amount of snow received increasing sharply with altitude, and snowpack temperatures decreasing with increasing altitude.

Of the two areas here with avalanche data, Bear Pass, Coast Mountains, is in a maritime snow climate (Haegeli, 2004; McClung and Schaerer, 2006) and Kootenay Pass, Columbia Mountains, is in a transitional one (Hägeli and McClung, 2003; Haegeli, 2004; McClung and Schaerer, 2006). The altitude dependence of the snow stations is also important. Bear Pass (Province of British Columbia, 1982) has an altitude of $450 \mathrm{~m}$ and is very close to the coast, and Kootenay Pass (Province of British Columbia, 1989) has an altitude of $1775 \mathrm{~m}$ with a location far into the interior of BC (Fig. 1). Appendix B (Tables 9 and 10) contains information to help place the stations in climate and altitude zones for BC

The total numbers of avalanches for 30 winters, stratified by water content of the debris, snow climate and altitude, 
Table 1. Total avalanches (size 2 or greater; Appendix A) for Bear Pass and Kootenay Pass, stratified by the water content of the debris (Fierz and others, 2009), from 1981/82 through 2010/11

\begin{tabular}{|c|c|c|c|c|c|}
\hline Avalanche area & Total dry avalanches & Total moist avalanches & Total wet avalanches & $\begin{array}{c}\text { Total with unrecorded } \\
\text { water content }\end{array}$ & Total avalanches \\
\hline Bear Pass & 5849 & 8777 & 3315 & 1044 & 18985 \\
\hline Kootenay Pass & 4194 & 1288 & 84 & 9 & 5575 \\
\hline
\end{tabular}

are listed in Table 1. The larger number of avalanches for Bear Pass (Table 1) arose mainly because Bear Pass (Province of British Columbia, 1982) has more active avalanche paths than Kootenay Pass (Province of British Columbia, 1989).

\subsection{Tests of significance for differences between means of annual maximum snow depth}

Sample statistics for annual maximum snow depth at the two snow stations showed that data were not highly skewed and the medians were equal to the means (Table 10 in Appendix $B)$. Thus, it is meaningful to compare the means of maximum snow depth for winters classified as El Niño and La Niña. Table 2 shows results of the $t$-tests on the means for strong La Niña $(x<-0.6)$ and strong El Niño $(x>0.6)$ years as well as the means for neutral years. The chosen level for statistical significance is the probability value $p \leq 0.05$ (Walpole and Myers, 1978) which is used throughout this paper.

The results (Table 2) show the mean of the maximum snow depths measured in strong La Niña years is higher than in neutral or strong El Niño years. I made similar calculations for Grouse Mountain, BC (maritime snow climate; 1126 ma.s.I.; latitude 49-23, longitude 132-04; $p=0.002$ ) and Mount Fidelity, Rogers Pass, BC (transitional snow climate; 1852 ma.s.l.; latitude 51-14, longitude 117$41 ; p<0.001$ ). All four stations (Fig. 1) exhibited higher annual maximum snow during strong La Niña winters, with three of the four (not Bear Pass) showing highly significant differences.

For comparison with Table 2, Mount Fidelity had means of $3.7 \mathrm{~m}$ (8 strong La Niña years), $3.2 \mathrm{~m}$ (29 neutral years) and $2.9 \mathrm{~m}$ (12 strong El Niño years), with $p=0.04$ for both La $\mathrm{Niña/neutral}$ and $\mathrm{El} \mathrm{Niño/neutral} t$-test comparisons. These indicated statistically significant differences between all three groups. Grouse Mountain had means of $4.0 \mathrm{~m} \mathrm{(12} \mathrm{La}$ Niña years), $2.8 \mathrm{~m}$ (36 neutral years) and $2.6 \mathrm{~m} \mathrm{(13}$ El Niño years), with $p=0.002$ for the $t$-test contrast between

Table 2. Mean of annual maximum snow on the ground for strong $\mathrm{El}$ Niño and La Niña winters including $t$-test results for significance of the differences. The differences are considered significant statistically for $p \leq 0.05$. The means increase in the order: El Niño $\rightarrow$ neutral $\rightarrow$ La Niña. The $p$-values for comparison of neutral years to El Niño and La Niña years are not significant $(p>0.05)$ except for neutral/La Niña at Kootenay Pass

\begin{tabular}{lcc}
\hline Quantity & Bear Pass & Kootenay Pass \\
\hline Mean $(m)-$ La Niña & 2.0 (6 years) & 3.5 (5 years) \\
Mean $(m)-$ neutral & 1.7 (23 years) & 2.9 (23 years) \\
Mean (m) - El Niño & 1.6 (9 years) & 2.8 (9 years $)$ \\
$p$-value: La Niña/El Niño & 0.085 & 0.007
\end{tabular}

La Niña/neutral years but without significant $(p=0.48)$ contrast between neutral and El Niño years. The ranking was the same for all four areas, with mean snow amounts decreasing in the order: La Niña $\rightarrow$ neutral $\rightarrow$ El Niño.

\section{COMPARISON OF SLAB AVALANCHE ACTIVITY AT BEAR PASS AND KOOTENAY PASS FOR LA NIÑA AND EL NIÑO WINTERS}

The effects of La Niña/El Niño on slab avalanche activity were studied for 30 winters of snow and avalanche records from 1981/82 through 2010/11 for Bear Pass and Kootenay Pass. The analysis included number of avalanches, avalanche size on the Canadian avalanche size classification system, and percentage of avalanches with deposits that were dry or wet.

Slab avalanches of sizes $\geq 2$ were analyzed. Size 1 avalanches were excluded since they consist mostly of small sloughs which are usually not harmful and are not considered in planning. Another reason for excluding size 1 avalanches is that many are small and unlikely to be recorded in highways operations since they may not reach highway level and lack of visibility may prevent accurate recording.

\subsection{Number and percentage of dry and wet avalanches}

Here I compare results for strong La Niña and El Niño years. Table 3 gives the results of $t$-tests on the annual means of the total number of avalanches ( $\geq$ size 2 ), the total number of dry and wet avalanches and the percentage of dry and wet avalanches. Analysis of moist avalanches was also completed, but there was no significant difference between the

Table 3. Significance ( $t$-tests for difference between the annual means) comparing strong El Niño and La Niña years with avalanche activity. The asterisk indicates lack of significance $(p>0.05)$. Variables not listed are not statistically significant. The $p$-values for comparison of neutral years to El Niño and La Niña years are not significant $(p>0.05)$

\begin{tabular}{lrrrr}
\hline Quantity & $\begin{array}{r}\text { La Niña } \\
\text { (annual } \\
\text { means) }\end{array}$ & $\begin{array}{r}\text { Neutral } \\
\text { (annual } \\
\text { means) }\end{array}$ & $\begin{array}{r}\text { El Niño } \\
\text { (annual } \\
\text { means) }\end{array}$ & $\begin{array}{r}\text { p-value: } \\
\text { La Niña/ } \\
\text { El Niño }\end{array}$ \\
\hline Total dry: Bear Pass & 242 & 217 & 121 & 0.04 \\
\% dry: Bear Pass & 42 & 33 & 25 & 0.02 \\
\% wet: Bear Pass & 13 & 17 & 25 & $0.36^{*}$ \\
Total number: Kootenay Pass & 228 & 221 & 131 & 0.05 \\
Total dry: Kootenay Pass & 187 & 149 & 95 & 0.03
\end{tabular}


Table 4. Rank correlations for snow and avalanche activity vs ONI for 30 years of records. The results are significant $(p=0.05)$ if the correlation coefficient is $\leq-0.305$. Variables not listed are not statistically significant

\begin{tabular}{ll}
\hline Quantity & ONI \\
\hline Max. annual snow depth: Bear Pass & -0.32 \\
Total number of dry avalanches: Bear Pass & -0.40 \\
\% dry avalanches: Bear Pass & -0.39 \\
Max. annual snow depth: Kootenay Pass & -0.30 \\
Total number of avalanches: Kootenay Pass & -0.33 \\
Total number of dry avalanches: Kootenay Pass & -0.32 \\
\hline
\end{tabular}

means for number or percentage for the two types of winter in this subsection or Section 4.2.

The data (Table 3) show that the total number of dry avalanches and the percentage of dry avalanches were significantly higher for Bear Pass during La Niña years. Although not statistically significant, the total number of wet avalanches (not shown in Table 3) and the percentage of wet avalanches were both higher during El Niño years for Bear Pass. Table 3 also contains annual means for neutral winters. The data show that neutral winters consistently had values intermediate between strong La Niña and El Niño winters, and the largest contrast between the three groups is between La Niña and El Niño winters.

The $t$-tests contained the assumption that variables were approximately Gaussian-distributed, which I verified for the variables in Table 3 by constructing probability plots. To compare the results with non-parametric assumptions, I repeated the calculations in Table 3 using Mann-Whitney $U$ tests based on ranks. The $p$-values were not altered except for total dry avalanches at both Bear Pass and Kootenay Pass. Both had $p=0.06$ (Mann-Whitney) compared to $p=0.04$ (Bear Pass) and $p=0.03$ (Kootenay Pass) using $t$-tests. Both Bear Pass and Kootenay Pass had mean and median values of total number of dry avalanches in strong La Niña years which were approximately double those in strong El Niño years.

The combined results (Tables 1-3) suggest more snow, more avalanches and a higher percentage of dry avalanches for La Niña winters, with the latter being strongly dependent on altitude and snow climate. The low-altitude Bear Pass location exhibited the effects of El Niño on the type of avalanche (wet or dry), whereas Kootenay Pass showed the effects of a higher, interior location with receipt of more snow and more avalanches during La Niña winters. The number of wet avalanches at Kootenay Pass was so low (Table 1) that the statistics had very little meaning. Both areas displayed a higher mean percentage of moist avalanches in El Niño years compared to La Niña, but the differences were not statistically significant $(p>0.05)$.

\subsection{Rank correlation of avalanche activity and snow amounts vs the Oceanic Niño Index (ONI)}

Table 4 contains Spearman rank correlation of avalanche activity variables, amounts of snow and the ONI to compare El Niño and La Niña winters. Since the ONI and maximum annual snow were not Gaussian-distributed, Spearman rank correlation coefficients are reported. The results (Table 4) are consistent with those in Table 3, showing a lower number and percentage of dry avalanches and amount of snow
Table 5. Rank correlations for variables that have significant rank correlation with maximum annual snow depth for 14 El Niño winters at Bear Pass. The critical value for significance is 0.457 $(p=0.05)$. The asterisk indicates lack of significance. Variables not reported are not statistically significant

Quantity

Max. annual snow depth (Bear Pass)

$\begin{array}{ll}\text { Total dry avalanches } & 0.63 \\ \text { Total moist avalanches } & 0.83 \\ \text { Total avalanches } & 0.93 \\ \text { Total avalanches (size } \geq 3) & 0.68 \\ \text { Total dry avalanches (size } \geq 3) & 0.03^{*}\end{array}$

during El Niño winters. The values (Table 4) are consistent for both areas since the total number of avalanches and total number of dry avalanches decreased during El Niño years.

\subsection{Rank correlation of avalanche activity vs the maximum annual snow depth}

Spearman rank correlations of avalanche activity variables vs the maximum annual snow depth are reported here for Bear Pass and Kootenay Pass, stratified by La Niña and El Niño winters

For Bear Pass (Table 5), there was no significant correlation with avalanche activity (number of avalanches, water content of debris, or size) with annual maximum snow amounts for La Niña winters. The total number of dry avalanches (size $\geq 3$ ) was included (Table 5) since it shows that the correlation of the total number of these large avalanches was due to moist and wet avalanches during $\mathrm{El}$ Niño winters. From Table 5, the strong effects of El Niño are evident on the water content of the avalanches at Bear Pass.

At Kootenay Pass (Table 6), in contrast, there was no significant correlation for avalanche activity and maximum snow depth during El Niño winters. The results in Table 6 (La Niña winters) and lack of significant correlation results for $\mathrm{El}$ Niño years show the dominance of the drier, colder conditions at Kootenay Pass. The results suggest that La Niña dominates the results at Kootenay Pass to yield more avalanches, more dry avalanches and a significant decrease in moist avalanches. Since the percentage of wet avalanches is so low at Kootenay Pass (Table 1), the percentage of moist avalanches must decrease as the percentage of dry avalanches increases.

The correlations of maximum annual snow amounts with the avalanche variables (Tables 5 and 6) are not trivial. Both the lack of significant correlations during La Niña winters at Bear Pass (Table 5) and the lack of significant correlations for El Niño winters at Kootenay Pass (Table 6) are important, as well as information on avalanche size.

Figure 5 contains time series for the annual total number of avalanches for Bear Pass and Kootenay Pass. For Bear Pass, the lowest avalanche total occurred in the record El Niño year of $1997(x=2.2)$ with the second lowest snow total. However, the highest avalanche total was in 2006, also an El Niño year $(x=0.6)$, but with the highest snow total. These results agree with Table 5 which shows high correlation (0.93) between total snow and total avalanches for El Niño winters. For Kootenay Pass, the highest total of avalanches was in a weak El Niño year $(1992 ; x=0.4)$ with a belowaverage snow total. However, the lowest avalanche total was 

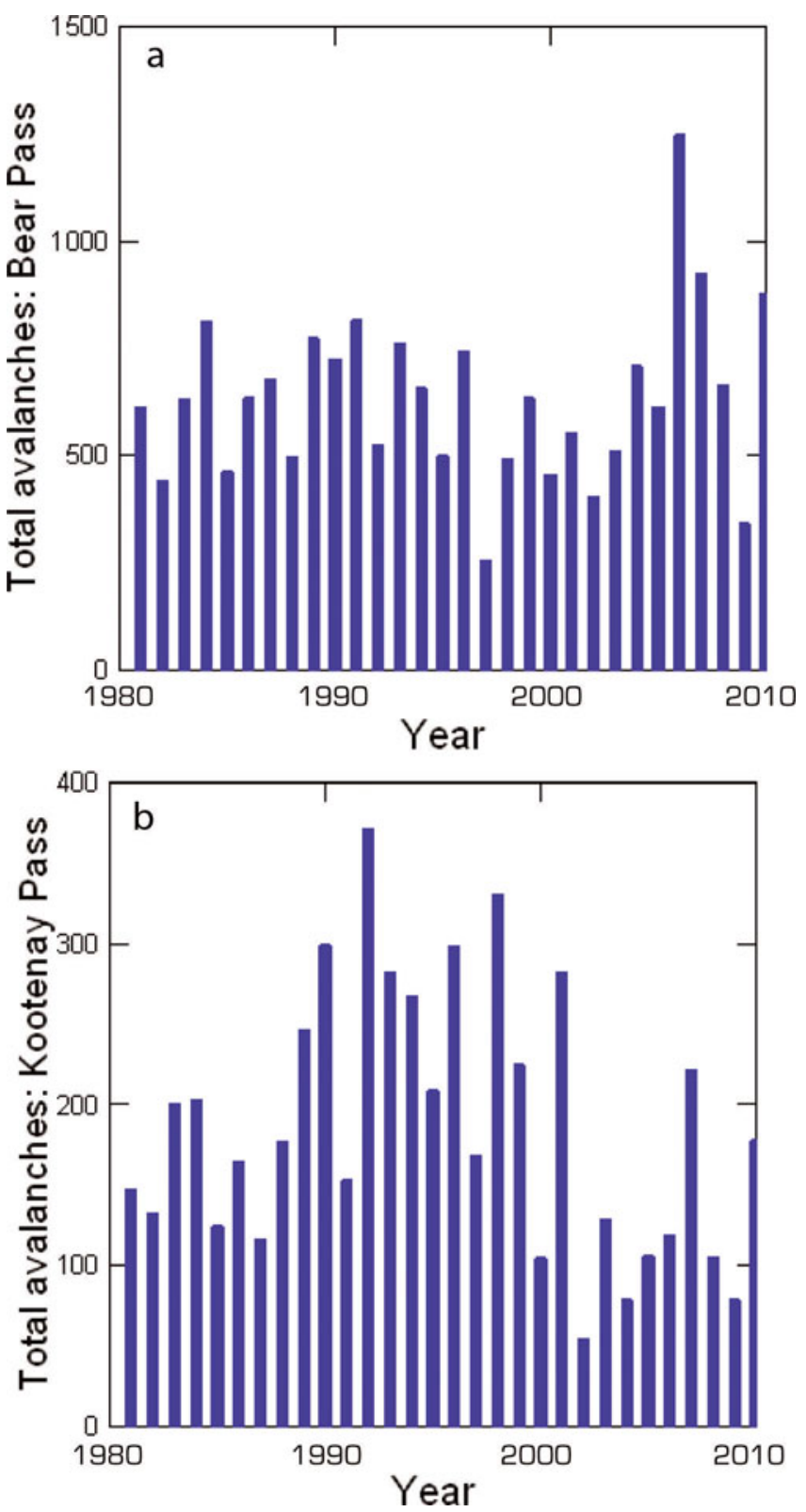

Fig. 5. Time series for total avalanches from (a) Bear Pass and (b) Kootenay Pass.

in a strong El Niño year $(2002 ; x=1.2)$ with snow total near the median. These results are consistent with the analysis from Kootenay Pass (Table 6) that total avalanches do not have significant rank correlation with total snow depth during El Niño winters. These extremes show complexity and that the correlations with the ONI (Table 4) can only be taken to apply on average, not to individual years.

\subsection{Results for large avalanches}

The previous results are largely for avalanches with sizes $\geq 2$. Bear Pass has enough avalanches for an analysis of large avalanches with size $\geq 3$. These are responsible for the majority of backcountry fatalities in Canada (CAA, 2011) and are of primary importance in land-use planning (CAA, 2002a,b).: However, size 2 avalanches account for about one-quarter of avalanche fatalities in Canada; they also block roads, and are much more numerous than size 3 avalanches.

The results of $t$-tests comparing the annual mean number of large avalanches (size $\geq 3$ ) and contrasting El Niño and
Table 6. Rank correlations for variables that have significant correlation with maximum annual snow depth for 13 La Niña winters at Kootenay Pass. The critical absolute value is 0.475 $(p=0.05)$. Variables not reported are not statistically significant

Quantity Max. annual snow depth
(Kootenay Pass)

Total dry avalanches

Total avalanches

0.59

$\%$ dry avalanches

0.47

$\%$ moist avalanches

$-0.54$

La Niña years showed no statistical difference between the two types of winter for either Bear Pass or Kootenay Pass. These results hold for either ONI grouping (1. outside $\pm 95 \%$ confidence limits on the mean; or 2. strong: $|x|>0.6)$.

At Bear Pass, rank correlation of total number of avalanches of sizes $\geq 3$ with the ONI (30 years of record) was -0.05 , which is not close to being statistically significant. Rank correlation of the total number of dry avalanches (size $\geq 3$ ) with the ONI (30 years of record) was -0.29 compared to the significance level $(-0.305)$.

Calculations were also made for the total numbers of avalanches and dry avalanches with sizes $\geq 3$ for Kootenay Pass. Results similar to Bear Pass were obtained, with no statistical difference between the mean numbers ( $t$-tests) for the two different types of winter. The rank correlations (sizes $\geq 3$ ) of the total number of avalanches and total number of dry avalanches with the ONI (30 years of record) were -0.16 and -0.22 respectively. These results and those in Table 5 are important since they imply that the character of an El Niño/ La Niña winter may not be important in land-use planning where extreme avalanches are considered. However, these results cannot be extrapolated to highway applications or backcountry travel, since size 2 avalanches are important for those applications.

\section{EFFECTS OF AVALANCHE CONTROL}

Avalanche paths at Kootenay Pass and Bear Pass are subject to avalanche control by use of explosives. At Kootenay Pass the majority of paths are regularly controlled by explosives while the proportion at Bear Pass is only 10\% (McClung, 2003). At Bear Pass, of 13475 avalanches (sizes $\geq 2$ ) with recorded triggers, $77 \%$ (10339) were naturals, with $23 \%$ (3136) triggered by explosives. For sizes $\geq 3,79 \%$ were naturals and $21 \%$ triggered by explosives. Thus, some of the Kootenay Pass results may be affected by avalanche control. However, this is less likely for Bear Pass. An analysis of avalanche paths both with and without avalanche control was performed at Rogers Pass on variables which affect avalanche frequency (McClung, 2003), and the results were nearly identical, indicating little effect of avalanche control on frequency.

Explosive control is used mainly to control the timing of avalanche release on highways so the public is not threatened. In order to achieve results with avalanche control, a slab and weak layer are required (as with any slab avalanche). The slab-weak-layer combination is not a product of avalanche control. Avalanche control will not affect the snow supply or water content. Time-series trend analysis (Fig. 5) for total number of avalanches (30 years; 
sizes $\geq 2$ ) from both Bear and Kootenay Pass using the Mann-Kendall test gave $p=0.33$ (Bear Pass) and $p=0.87$ (Kootenay Pass). Both imply no significant time trend in the number of avalanches.

The main objective of this paper is to understand the pattern of avalanching in relation to El Niño/La Niña effects. In general, the avalanching pattern is heavily influenced by snow supply (Smith and McClung, 1997; McClung, 2003). The most likely effect of avalanche control should be on the size distribution, with a slight predominance of smaller avalanches. However, the main avalanche size result in this paper comes from Bear Pass which is not subject to heavy avalanche control. At Bear Pass, the median and mean sizes for avalanches (sizes $\geq 2$ ) were found to be the same (size 2.5) both for avalanches triggered by explosives and naturals.

\section{ANALYSIS OF SNOW DATA FOR THE CENTRAL CHILEAN ANDES}

Here I present analysis of snow data from high-mountain stations at El Indio and Minera Los Pelambres. No companion avalanche records exist and temperature data are not available. The data consist of total storm snow amounts for 24 years (1981-2004) for El Indio and 21 years (1990-2010) at Minera Los Pelambres.

For El Indio, $t$-tests for the difference in means (total storm snow) for all years gave $3.5 \mathrm{~m}$ (El Niño years) compared with $1.7 \mathrm{~m}$ (La Niña years) $(p=0.06)$ and $4.3 \mathrm{~m}$ (7 strong El Niño years) and $1.2 \mathrm{~m}$ (3 strong La Niña years) $(p=0.05)$. These results are opposite to those from $\mathrm{BC}$, which show more snow in La Niña years. Rank correlation of the ONI with total snow amounts gave 0.59 (24 years; $p<0.005), 0.68$ (12 El Niño years; $p<0.025)$ and 0.10 (10 La Niña years), with the latter not being significant. The data from Minera Los Pelambres had Spearman rank correlation with the ONI vs total snowfall of 0.40 (21 years; $p<0.05$ ) with 0.99 (6 strong El Niño years; $p<0.01$ ) and 0.00 (3 strong La Niña years).

Cross-correlation time-series analysis of maximum snow amounts with the ONI showed significant positive correlation at zero lag for the two Chilean stations and significant negative correlation for all four stations in BC. Figure 6 shows cross-correlation plots from Grouse Mountain, BC, and Minera Los Pelambres, Chile. The Chilean results are opposite to those for BC, which is characterized by high snow amounts in La Niña years and negative correlation with the ONI (Table 4). For the largest value of the ONI (2.2 in 1997; Fig. 4), the third highest snow total was measured at El Indio $(7.0 \mathrm{~m})$ and the largest storm total $(7.2 \mathrm{~m})$ was measured at Minera Los Pelambres. For 1997/98, Bear Pass had the lowest total number of avalanches and second lowest snow total for the 30 years of record. The corresponding prediction for the central Chilean Andes is the opposite: a relatively high number of avalanches for 1997. In fact, extensive and exceptional avalanche activity was observed in central Chile during 1997 (personal communication from C.J. Stethem, 2012). Since snow supply is a primary determinant of avalanche frequency (Smith and McClung, 1997; McClung, 2003) this is expected.

Without avalanche records, the expectation for El Niño winters to be big avalanche winters in central Chile was not confirmed here. However, León (1978) reported statistics for 182 avalanche fatalities in central Chile (1926-76), including accidents (fatalities in parentheses) in the El Niño years (Bryant, 2005) of 1926 (9), 1941 (7) and 1944 (120).
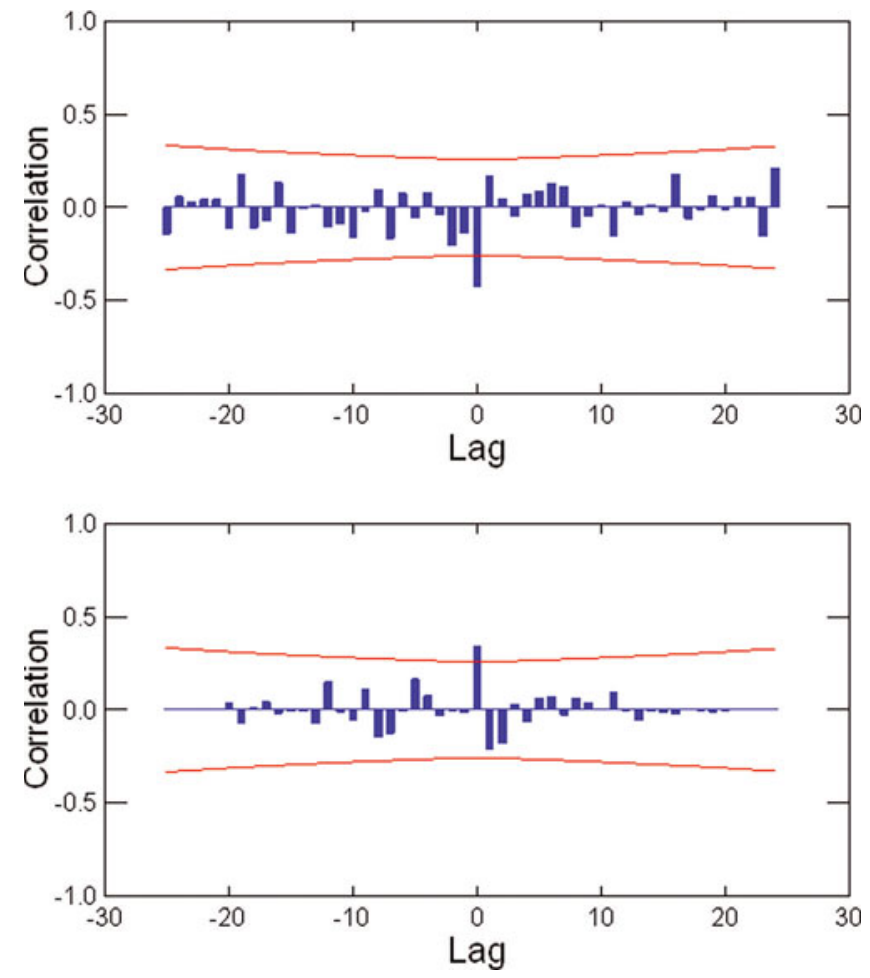

Fig. 6. Cross-correlation time-series plots of maximum snow depth vs ONI: (a) Grouse Mountain, BC, showing negative correlation at lag zero; and (b) Minera Los Pelambres, Chile, showing positive correlation with total annual snowfall amounts. The correlations are significant when they fall outside the lines representing two standard errors.

Of accidents before 1950, only one was not in an El Niño year, in 1936 (3). Years with fatal accidents reported since 1950 (with ONI in parentheses) included: 1953 (0.4); 1959 (-0.3); 1965 (1.0): 2 accidents; 1969 (0.6); and 1972 (1.2). In addition, the Boston Globe newspaper reported 2 dead and more than 60 missing on 30 November 1987 (1.6). Thus, only 1 of the 7 fatal accidents since 1950 occurred during a weak La Niña year (1959), with 4 of the remaining 6 accidents occurring during strong El Niño years, and another with a large ONI of 0.6. Of fatal accidents reported since 1926, 10 were in El Niño years and 2 were not. León (1978) provided a detailed description of the Caracoles railway accident in the big El Niño year of 1941 (7) and reported that the same large, climax-type avalanche ran again in the strong El Niño year 1972 (ONI of 1.2) but with no fatalities.

The snow data from Chile are important since they show that the results from $\mathrm{BC}$ cannot be easily extrapolated to other areas. In fact, the picture is quite complex. The results from central Chile should not be extended north, even as far as the Bolivian Altiplano which generally experiences drought during El Niño (Vuille and others, 2008). Glaciar Zongo, Cordillera Real, Bolivia (16-25 S, 68-17 W; Les Services d'Observation GLACIOCLIM, 2012) has mass balance controlled by precipitation variability (Vuille and others, 2008). I calculated rank correlation with annual net mass-balance data with the ONI from Glaciar Zongo for 19 years of data. I obtained rank correlation $-0.57(p<0.01)$. The highest negative mass balance was from the record $\mathrm{El}$ Niño year of 1997, which implies the opposite of the snowfall records from central Chile. 


\section{CONCLUSIONS AND DISCUSSION}

The results suggest that altitude and snow climate affect both the temperature regime and the amount of snow which control the pattern of avalanching. In BC more snow arrives during La Niña winters and this is linked to the higher numbers of avalanches.

Stahl and others (2006) showed that El Niño winters are warmer than normal in southern BC and along the coast, while La Niña winters are colder than normal along the coast and in central and northern BC. More importantly, Stahl and others (2006) showed that winter temperatures are significantly lower in La Niña years than in El Niño years. Temperature effects are not directly analyzed here but are evident in the data and consistent with the analysis of Stahl and others (2006). At Bear Pass, the mix of water content of avalanche debris was affected, with double the percentage of wet avalanches at Bear Pass for El Niño compared to La Niña years and a progressive increase in water content from La Niña $\rightarrow$ neutral $\rightarrow$ El Niño. The colder La Niña winters show an increasing percentage of dry avalanches at Kootenay Pass compared to moist. For both Bear Pass and Kootenay Pass, the snow supply (Table 2) and total numbers of avalanches (Table 3) follow the same trend decreasing from La Niña $\rightarrow$ neutral $\rightarrow$ El Niño winters. Not all differences between the three groups of winters are statistically significant, but the trends found in all variables (Table 3) show that differences between the three groups cannot be dismissed as insignificant.

El Niño/La Niña modify both winter temperatures and snowfall in BC (Moore and McKendry, 1996; Stahl and others, 2006). Temperature effects on avalanche forecasting have been analyzed extensively at both Kootenay Pass (McClung and Tweedy, 1994) and Bear Pass (Floyer, 2003; Floyer and McClung, 2003). The results of the forecasting temperature analyses are in excellent correspondence with the snow and avalanche patterns in this paper and the results of Stahl and others (2006).

At Kootenay Pass, temperature is not a significant predictor for dry avalanches (McClung and Tweedy, 1994). Most of the avalanches here are dry (Table 1). Table 3 shows that at Kootenay Pass the only significant variables in the progression La Niña $\rightarrow$ El Niño winters are decreases in total number and total number of dry avalanches. The significant snow total differences (Table 2) dominate in this case. The reason is that Kootenay Pass is a cold, high-elevation location far from the coast so that the effects of El Niño (Table 6) do not dominate. At Kootenay Pass, the only significant variable directly associated with temperature effects in all the tables is percent decrease in moist avalanches correlated with maximum annual snow depth for La Niña winters (Table 6).

At Bear Pass (Floyer, 2003; Floyer and McClung, 2003), present temperature, in combination with snowfall, is the most significant variable for predicting dry avalanches, but the correlation is negative, meaning decreasing chance of dry avalanches with increasing temperature. For Bear Pass (Table 3), the most significant change in the progression La $\mathrm{Niña} \rightarrow \mathrm{El} \mathrm{Niño}$ is the percent decrease in dry avalanches and there is also a progressive increase in percent wet avalanches. The snow totals also decrease from La Niña $\rightarrow$ El Niño, but the differences are not statistically significant (Table 2). At Bear Pass, the results show that for El Niño (Table 5) the associated temperature and snowfall effects dominate for the low-altitude, coastal location. However, at
Kootenay Pass, La Niña (Table 6) and the associated increased snow amounts dominate (Table 2) for the highaltitude, interior location.

The avalanche results (Tables 3-6) are consistent with those of Stahl and others (2006): warmer conditions with less snow during El Niño winters and the reverse in La Niña winters for BC. These results, although expected, are not trivial. From the perspective of global climate change, the results suggest that both mountain snowfall amounts and winter temperatures must be predicted a long time into the future in order to specify the pattern of snow avalanching.

The occurrence of El Niño and La Niña winters is predictable. My results suggest that the general character of snow avalanche activity in a given winter can be roughly predicted, which may facilitate planning. In BC, La Niña brings more snow and lower temperatures which are good for tourism since better skiing is likely. However, La Niña should bring an increase in the total number of avalanches and the percentage of dry ones. Dry avalanches are the major concern for BC's industries since they generate the highest impact forces, run the furthest (McClung and Schaerer, 2006) and kill the most people (CAA, 2011). In central Chile, El Niño brings the big snow years. In Chile, avalanches impact on transportation routes, mining and tourism (León, 1976). The link to climate is also of interest for the study of glaciers since snow avalanching makes an important contribution to mass balance of glaciers (Benn and Evans, 1998), whose accumulation zones are bordered by steep terrain.

The results showing lack of correlation for avalanches of sizes $\geq 3$ must be treated carefully. Size 2 avalanches are important for backcountry safety purposes since they account for a significant number of avalanche fatalities (CAA, 2011). Size 2 avalanches can also block highway and railway lines. For land-use planning such as for occupied buildings where return periods of avalanches are on the order of hundreds of years, my results suggest El Niño/La Niña effects are not significant.

Avalanches of sizes $\geq 3$ often have persistent forms (surface hoar, facets, depth hoar) as weak layers rather than new snow (Haegeli, 2004). Such weak-layer forms require short-term (1 day to weeks) periods of good weather for their formation. Thus, the formation of such large avalanches often depends importantly on weather in addition to the effects of climate. The need for persistent-form weak layers may help to explain the lack of correlation of large avalanches with the effects of El Niño/La Niña, but it cannot be proven with the data in this paper.

This paper is the first to illustrate avalanche patterns likely as a result of El Niño/La Niña. However, the effects of El Niño/La Niña should not be taken, in general, as dominant. People forecast avalanches on the basis of current conditions and weather, not climate (McClung and Schaerer, 2006), and the El Niño/La Niña contrast is only one of several climate effects. Many of the correlations in this paper are just at or above the significance level $(p \leq 0.05)$, and that is expected since there are numerous factors that determine the pattern of slab avalanches. What this paper demonstrates is that the effect of El Niño/La Niña is one of those factors. The time-series analysis for total avalanches (Section 4.3; Fig. 5) clearly shows that one cannot form expectations entirely on the basis of a general prediction for an El Niño/ La Niña winter. 


\section{ACKNOWLEDGEMENTS}

This work was funded by the Natural Science and Engineering Research Council of Canada, Canadian Mountain Holidays and the University of British Columbia. Avalanche occurrence records were provided by the Ministry of Transportation and Infrastructure, Victoria, British Columbia, Canada. I am grateful for all of the support and data records.

\section{REFERENCES}

Armstrong RL and Armstrong BR (1987) Snow and avalanche climates of the western United States: a comparison of maritime, intermountain and continental conditions. IAHS Publ. 162 (Symposium at Davos 1986 - Avalanche Formation, Movement and Effects), 281-294

Benn DI and Evans DJA (1998) Glaciers and glaciation. Arnold, London

Bryant E (2005) Natural hazards, 2nd edn. Cambridge University Press, Cambridge

Canadian Avalanche Association (CAA) (2002a) Guidelines for snow avalanche risk determination and mapping. Canadian Avalanche Association, Revelstoke, B.C.

CAA (2002b) Land managers' guide to snow avalanche hazards in Canada. Canadian Avalanche Association, Revelstoke, B.C.

CAA (2007) Observation guidelines and recording standards for weather, snowpack, and avalanches. Canadian Avalanche Association, Revelstoke, B.C.

CAA (2011) Avalanche incident reports. http://www.avalanche.ca/ cac/library/incident-report-database/view

Castebrunet H, Eckert N and Giraud G (2012) Snow and weather climatic control on snow avalanche occurrence fluctuations over $50 \mathrm{yr}$ in the French Alps. Climate Past, 8(2), 855-875 (doi: $10.5194 / \mathrm{cp}-8-855-2012$ )

Fierz C and 8 others (2009) The international classification for seasonal snow on the ground. (IHP Technical Documents in Hydrology 83) UNESCO-International Hydrological Programme, Paris

Fitzharris BB (1981) Frequency and climatology of major avalanches at Rogers Pass, 1909 to 1977. (DBR Paper 956/NRCC Paper 19020) Division of Building Research, National Research Council of Canada, Ottawa, Ont.

Floyer JA (2003) Statistical avalanche forecasting using meteorological data from Bear Pass, British Columbia, Canada. (MSc thesis, University of British Columbia)

Floyer JA and McClung DM (2003) Numerical avalanche prediction: Bear Pass, British Columbia, Canada. Cold Reg. Sci. Technol., 37(3), 333-342 (doi: 10.1016/S0165-232X(03)00074-0)

García-Sellés C, Peña JC, Marti G, Oller P and Martinez P (2010) WeMOI and NAOi influence on major avalanche activity in the Eastern Pyrenees. Cold Reg. Sci. Technol., 64(2), 137-145 (doi: 10.1016/j.coldregions.2010.08.003)

Haegeli PT (2004) Scale analysis of avalanche activity on persistent snowpack weaknesses with respect to large-scale backcountry avalanche forecasting. (PhD thesis, University of British Columbia)

Hägeli P and McClung DM (2003) Avalanche characteristics of a transitional snow climate - Columbia Mountains, British Columbia, Canada. Cold Reg. Sci. Technol., 37(3), 255-276 (doi: 10.1016/S0165-232X(03)00069-7)

Keylock CJ (2003) The North Atlantic Oscillation and snow avalanching in Iceland. Geophys. Res. Lett., 30(5), 1254 (doi: 10.1029/2002GL016272)

Laternser M and Schneebeli M (2002) Temporal trend and spatial distribution of avalanche activity during the last 50 years in Switzerland. Natur. Hazards, 27(3), 201-230 (doi: 10.1023/ A:1020327312719)
León RE (1978) An avalanche tragedy in Chile. In Perla R ed. Proceedings of the International Snow Science Workshop, 1-4 November 1976, Banff, Alberta. National Research Council Canada, Ottawa, Ont., 219-224

Les Services d'Observation GLACIOCLIM (2012) Les sites de mesure de GLACIOCLIM-Andes. Laboratoire de Glaciologie et Géophysique de I'Environnement, Grenoble http://wwwIgge.ujf-grenoble.fr/ServiceObs/SiteWebAndes/sitesmesure.htm

McClung DM (2003) Magnitude and frequency of avalanches in relation to terrain and forest cover. Arct. Antarct. Alp. Res., 35(1), 82-90

McClung D and Schaerer P (2006) The avalanche handbook, 3rd edn. The Mountaineers, Seattle, WA

McClung DM and Tweedy J (1994) Numerical avalanche prediction: Kootenay Pass, British Columbia, Canada. J. Glaciol., 40(135), 350-358

Moore RD and McKendry IG (1996) Spring snowpack anomaly patterns and winter climatic variability, British Columbia, Canada. Water Resour. Res., 32(3), 623-632 (doi: 10.1029/ 95WR03640)

Province of British Columbia. Ministry of Environment (2011) Historic snow survey data: station selection. Province of British Columbia, Ministry of Environment http://a100.gov.bc.ca/pub/ mss/stationlist.do

Province of British Columbia. Ministry of Transportation and Highways, Snow Avalanche Section (1982) Snow avalanche atlas, Bear Pass, Stewart-Hyder. Province of British Columbia, Ministry of Transportation and Highways, Vancouver, B.C.

Province of British Columbia. Ministry of Transportation and Highways, Snow Avalanche Section (1989) Snow avalanche atlas: Kootenay Pass, 2nd edn. Province of British Columbia, Ministry of Transportation and Highways, Vancouver, B.C.

Redmond K (2005) Classification of El Niño and La Niña winters. Western Regional Climate Center, Desert Research Institute, Reno, NV http://www.wrcc.dri.edu/enso/ensodef.html

Smith MJ and McClung DM (1997) Avalanche frequency and terrain characteristics at Rogers Pass, British Columbia, Canada. J. Glaciol., 43(143), 165-171

Stahl K, Moore RD and McKendry IG (2006) The role of synopticscale circulation in the linkage between large-scale oceanatmosphere indices and winter surface climate in British Columbia, Canada. Int. J. Climatol., 26(4), 541-560 (doi: 10.1002/joc.1268)

US National Weather Service (USNWS), Climate Prediction Center (2011) Cold and warm episodes by season: changes to the Oceanic Niño Index (ONI). National Oceanic and Atmospheric Administration, Madison, WI http://www.cpc. ncep.noaa.gov/products/analysis_monitoring/ensostuff/ ensoyears.shtml

Vuille M, Kaser G and Juen I (2008) Glacier mass balance variability in the Cordillera Blanca, Peru and its relationship with climate and the large-scale circulation. Global Planet. Change, 62(1-2), 14-18 (doi: 10.1016/j.gloplacha.2007.11.003)

Walpole R and Myers R (1978) Probability and statistics for engineers and scientists, 2nd edn. Macmillan, New York

\section{APPENDIX A: SUMMARY OF THE CANADIAN AVALANCHE SIZE CLASSIFICATION SYSTEM AND LIST OF VARIABLES}

Table 7 contains the Canadian avalanche size classification and the descriptors.

The basic variables used in this study are listed in Table 8 along with descriptions. All variables refer to totals for each snow season.

In Table 8, the water content (dry, moist, wet) (McClung and Schaerer, 2006; Fierz and others, 2009) refers to that in the deposit of the avalanche. 
Table 7. The Canadian avalanche size classification system based on destructive potential

\begin{tabular}{|c|c|c|c|c|}
\hline Size & Description & Typical mass & $\begin{array}{c}\text { Typical } \\
\text { path length }\end{array}$ & $\begin{array}{c}\text { Typical } \\
\text { impact pressure }\end{array}$ \\
\hline & & $\mathrm{t}$ & $\mathrm{m}$ & $\mathrm{kPa}$ \\
\hline 1 & Relatively harmless to people & $<10$ & 10 & 1 \\
\hline 2 & Could bury, injure or kill a person & 100 & 100 & 10 \\
\hline 3 & Could bury a car, destroy a small building or break a few trees & 1000 & 1000 & 100 \\
\hline 4 & Could destroy a railway car, large truck, several buildings or a forest with area up to 4 ha & 10000 & 2000 & 500 \\
\hline 5 & Largest snow avalanches known; could destroy a village or forest of 40 ha & 100000 & 3000 & 1000 \\
\hline
\end{tabular}

Table 8. Variables used in the study

Quantity Description

Maximum annual snow depth

Total snow amount summed over the winter

Total number of dry avalanches

Total number of moist avalanches

Total number of wet avalanches
Bear Pass; Grouse Mountain; Kootenay Pass; Mount Fidelity: all in BC

El Indio and Minera Los Pelambres, Chile: Section 6 Stratified by size with sums for size $\geq 2$ and size $\geq 3$ : Bear Pass and Kootenay Pass Stratified by size with sums for size $\geq 2$ and size $\geq 3$ : Bear Pass and Kootenay Pass Stratified by size with sums for size $\geq 2$ and size $\geq 3$ : Bear Pass and Kootenay Pass

\section{APPENDIX B: DESCRIPTIVE STATISTICS FOR BEAR PASS AND KOOTENAY PASS}

Table 9 contains the basic characteristics and locations for both areas. Table 10 contains a summary of the basic descriptive statistics for both stations. All values refer to the maximum snow depth measured each winter.

Table 9. Characteristics of the two snow stations in BC

\begin{tabular}{lcccc}
\hline Station & Elevation & Snow climate & Lat. (N) & Long. (W) \\
& ma.s.l. & & \\
\hline Bear Pass & 450 & Maritime & $56-06$ & $129-40$ \\
Kootenay Pass & 1775 & Transitional & $49-06$ & $117-04$ \\
\hline
\end{tabular}

Table 10. Descriptive statistics for the snow stations considered. All values are from annual maximum values of snow depth

\begin{tabular}{lcc}
\hline Quantity & Bear Pass & Kootenay Pass \\
\hline Number of years & 38 & 37 \\
Min. (m) & 0.8 & 2.3 \\
Max. (m) & 2.9 & 3.8 \\
Median $(\mathrm{m})$ & 1.7 & 3.0 \\
Mean $(\mathrm{m})$ & 1.7 & 3.0 \\
\hline
\end{tabular}

MS received 13 October 2012 and accepted in revised form 11 April 2013 